\title{
Infant malnutrition in a developed country
}

During the present century there have been major changes in the way babies are fed in this country. During the first 25 or 30 years of the century breast feeding was accepted as the usual method and it was often maintained for 9 months or more. Where breast feeding was not available, the principles propounded by enthusiasts such as Truby King gained some popularity; cow's milk was 'humanized' by dilution and with additions of cream and carbohydrate, so that the percentages of protein, fat, and carbohydrate approximated to those of human milk. In retrospect it can be seen how reasonable was that approach.

In the war years, 1939-45, the introduction of a National Dried Milk popularized a type of formula which meant that effectively babies were fed on a formula differing not greatly from cow's milk, with the high protein intake that this entails. The simplicity of this method, and the fact that most babies manifestly thrived on it, led to its continued acceptance in the post-war era. The 1950 s were also marked by a general laissez-faire approach of paediatricians towards infant feeding, and a faintly derisive attitude towards the idea that overfeedingonce a common enough diagnosis-could be a serious matter.

Coming to the last decade, the continued lack of interest of paediatricians as a whole in the subject of infant feeding has meant that the advice mothers have needed has come to be supplied by others; by doctors other than paediatricians working in infant welfare centres, but more often by nurses and health visitors, by women's magazines, and by commercial firms. Paediatricians, having in effect abrogated their responsibilities in this field, must accept responsibility for the present state of affairs.

Whereas this journal continues to get offered an abundance of papers reporting biochemical nuances detectable in malnourished children in the underdeveloped countries, conspicuous by their absence have been communications from nearer home about the effect of the infant feeding regimens current in this country. Fortunately there are signs of a long overdue reawakening of interest by paediatricians in the subject, and a number of authors who have looked at normal babies and how they are fed have expressed serious concern at what they have found. Taitz ${ }^{1}$ in Sheffield documented the fact that babies there were commonly receiving solids from the first few weeks of life, and that by 6 weeks many were much heavier than would be expected on the basis of the standard growth curves which have been accepted in both Europe and North America for many years. Workers in Birmingham, ${ }^{2}$ observing babies up to 1 year, made the same point, that overnutrition, both in terms of calories and of protein intake, is now common. They have underlined the question, 'How far is obesity in infancy a cause of obesity in later life ?'. Taitz and Byers $^{3}$ and Shaw and co-workers ${ }^{4}$ have drawn attention to the high osmotic and mineral loads imposed on the infant when many of the commercial infant feeds are made up correctly, and how easy it is to raise these loads to dangerous levels merely by a haphazard use of the scoop as a measure of dry powder. In this issue of the Archives Davies and Saunders ${ }^{5}$ report that, presumably as a result of a combination of these factors, the blood urea level measured in normal 1- to 3-month-old infants artificially fed was frequently well above the accepted upper limit of normal of $40 \mathrm{mg} / 100 \mathrm{ml}$, and sometimes was as high as $70 \mathrm{mg} / 100 \mathrm{ml}$.

Will facts such as these spur paediatricians to take up their proper place in the community as advisers on child care, with sound nutrition as a cornerstone of that care?

\section{REFERENCES}

1Taitz, L. S. (1971). Infantile overnutrition among artificially fed infants in the Sheffield region. British Medical fournal, 1, 315.

2Shukla, A., Forsyth, H. A., Anderson, C. M., and Marwah, S. M. (1972). Infantile overnutrition in the first year of life: a field study in Dudley, Worcestershire. British Medical fournal, 4, 507.

3Taitz, L. S., and Byers, H. D. (1972). High calorie/osmolar feeding and hypertonic dehydration. Archives of Disease in Childhood, 47, 257.

${ }^{4}$ Shaw, J. C. L., Jones, A., and Gunther, M. (1973). Mineral content of brands of milk for infant feeding. British Medical fournal, $2,12$.

5Davies, D. P., and Saunders, R. (1973). Blood urea: normal values in early infancy related to feeding practices. Archives of Disease in Childhood, 48, 563. 